UDC 902.01

Submitted: 17.01.2019

LBC 63.4(2)

Accepted: 25.02.2019

\title{
THE COMPLEX OF BRONZE SNAFFLES FROM THE AREA OF MALYE SEMIBRATNYE BARROWS
}

\author{
Andrey M. Novichikhin \\ Anapa Archaeological Museum, Anapa, Russian Federation
}

\begin{abstract}
Anapa archaeological museum stores a bronze snaffle complex, which was found on arable lands near Chekon khutor in 2013. The complex was found in the area of the barrow group known as Malye Semibratnye barrows. Complex includes two pairs of two-hole snaffles: a pair with a sickle-shaped blade and an L-shaped pair. Sickle-shaped snaffles have analogies in the materials of the IV Semibratnyy barrow. L-shaped snaffles are among the most common ones in Scythian burial monuments. They are famous by finds from the burial mounds of the necropolis of Nymphaeum and Semibratnye barrows. The existing analogies allow us to date the complex to the $5^{\text {th }}$ century BC. The complex of horse equipment items found in the inter-burial space is similar to the topography of Scythian and early Sarmatian necropolises famous for individual burial complexes and complexes of ritual items including horse equipment found outside of the barrows. Perhaps the complex was a set of pair horse harness of a funeral wagon. The discovery expands the idea of the funeral and memorial rites of the Sindian nobility, allowing to connect it with traditions that existed in the Scythian and early Sarmatian societies.
\end{abstract}

Key words: Sindika, Semibratnye barrows, horse equipment, Scythians, Sarmatians, Sindans.

Citation. Novichikhin A.M., 2019. The Complex of Bronze Snaffles from the Area of Malye Semibratnye Barrows. The Lower Volga Archaeological Bulletin, vol. 18, no. 1, pp. 74-80. (in Russian). DOI: https://doi.org/ 10.15688/nav.jvolsu.2019.1.6

УДК 902.01

Дата поступления статьи: 17.01.2019

ББК $63.4(2)$

Дата принятия статьи: 25.02.2019

\section{КОМПЛЕКС БРОНЗОВЫХ ПСАЛИЕВ ИЗ РАЙОНА МАЛЫХ СЕМИБРАТНИХ КУРГАНОВ}

\author{
Андрей Михайлович Новичихин \\ Анапский археологический музей, г. Анапа, Российская Федерация
}

\begin{abstract}
Аннотация. В Анапском археологическом музее хранится комплекс бронзовых псалиев, найденный на пашне близ хут. Чекон в 2013 году. Находка сделана в районе курганной группы, известной как Малые Семибратние курганы. Комплекс включает две пары двудырчатых псалиев: пару с серповидной лопастью и пару Г-образных. Серповидные псалии имеют аналогии в материалах IV Семибратнего кургана. Г-образные псалии относятся к числу наиболее распространенных в скифских погребальных памятниках. Известны они по находкам в курганных погребениях некрополя Нимфея и в Семибратних курганах. Имеющиеся аналогии позволяют датировать комплекс V в. до н.э. Находка комплекса предметов конского снаряжения в межкурганном пространстве находит аналогии в топографии скифских и раннесарматских некрополей, в которых известны отдельные погребения и комплексы ритуальных предметов, в том числе и конского снаряжения, обнаруженные за пределами курганных насыпей. Возможно, комплекс представлял собой набор парной конской упряжи погребальной повозки. Находка расширяет представления о погребально-поминальной обрядности синдской знати, позволяя связывать ее с традициями, существовавшими в скифском и раннесарматском обществах.

Ключевые слова: Синдика, Семибратние курганы, конское снаряжение, скифы, сарматы, синды.

Цитирование. Новичихин А. М., 2019. Комплекс бронзовых псалиев из района Малых Семибратних курганов // Нижневолжский археологический вестник. Т. 18, № 1. С. 74-80. DOI: https://doi.org/10.15688/ nav.jvolsu.2019.1.6
\end{abstract}


В 2013 г. в Анапский археологический музей поступил комплекс древних предметов - две пары бронзовых псалиев. Об обстоятельствах находки известно лишь то, что псалии обнаружены на пашне приблизительно в 1 км северо-западнее хут. Чекон Первомайского сельского округа города-курорта Анапа.

К северо-западу от хут. Чекон расположена курганная группа, известная как Малые Семибратние курганы. Название эта курганная группа получила по месторасположению поблизости от более известного курганного некрополя - Семибратних курганов, или Больших Семибратних курганов, исследовавшихся в 1875, 1876 и 1878 гг. членом Императорской археологической комиссии В.Г. Тизенгаузеном [Коровина, 1957, с. 174; Власова, 2001, c. 127; Тункина, 2010 , с. 63]. В отличие от Больших Семибратних курганов, расположенных относительно компактной цепью, Малые Семибратние рассредоточены на большом пространстве и их насыпи не столь внушительны. Несколько курганов группы Малых Семибратних также были исследованы В.Г. Тизенгаузеном, но, к сожалению, эти раскопки плохо документированы [Коровина, 1957, c. 174; Власова, 2001, с. 128]. Малые Семибратние курганы являются частью некрополя Семибратнего городища - античной Лабриты. И Большие, и Малые Семибратние курганы связываются с захоронениями представители синдской знати - царей и высшей аристократии [Власова, 2001, с. 129-131; Горончаровский, 2013, с. 230-233].

Е.В. Власова, основываясь на материалах В.Г. Тизенгаузена из архива ИИМК, пишет, что в группу Малых Семибратних входило 7 [Власова, 2001, с. 128] или, по другим сведениям, 15 курганов [Власова, 2010, с. 205; Тункина, 2010, с. 63]. По данным А.И. Салова, курганная группа у хут. Чекон насчитывает 11 насыпей [Салов, 1979, с. 101, 40a, 41].

Поступившие в Анапский археологический музей бронзовые псалии образуют двепары.

Первую пару (рис. 1,1,2) составляют крупные (длина 26 и 27 см) двудырчатые псалии, один конец которых прямой, в виде круглого в сечении, слегка расширяющегося к концу стержня, а противоположный оформлен в виде серповидной, сужающейся к концу лопасти. В средней части псалиев имеется восьмер- кообразное расширение с двумя сквозными отверстиями. Между отверстиями на обоих экземплярах видны следы окислов железа от удил. Судя по всему, оба псалия были отлиты в одной форме, но при последующей доработке их лопасти приобрели разное сечение - у одного оно имеет форму вытянутого прямоугольника, у другого, за счет фасок по одной из сторон, - форму вытянутой трапеции. Оба псалия повреждены: у одного обломан кончик лопасти, у другого лопасть сломана у основания (на этом экземпляре заметны также раковины-поры, образовавшиеся при литье). Псалии покрыты зеленовато-серой, слегка блестящей патиной.

Вторую пару (рис. 1,3,4) составляют двудырчатые псалии Г-образной формы длиной 12,5 и 12,6 см. Один их конец прямой, в виде круглого в сечении стержня, расширяющегося к концу, другой, также круглый в сечении, изогнут под углом, близким к прямому. Псалии отлиты в разных формах и из металла разного качества: один из них покрыт зеленовато-серой, слегка блестящей патиной, другой - шершавой зеленой. Отличается также и оформление нижнего и верхнего окончания стержней. Оба псалия имеют в средней части восьмеркообразное расширение с двумя сквозными отверстиями, причем у одного из экземпляров (с зеленовато-серой патиной) окаймляющие отверстия расширения с одной из сторон снабжены выступами-шипами, предназначенными для «строгого» управления верховым конем. На перемычке между отверстиями также присутствуют следы железных окислов от удил.

Единственной достаточно близкой аналогией экземплярам с серповидной лопастью является бронзовый двудырчатый псалий из «конской гробницы» V Семибратнего кургана, запечатленный Ф.И. Гроссом на одном из хранящимся в архиве ИИМК рисунков [Тункина, 2010, рис. 46]. Курган датировался исследователями в пределах второй половины $\mathrm{V}$ в. до н.э., в настоящее время его сооружение относят к последней четверти $\mathrm{V}$ в. до н.э. времени около 430-420 гг. до н.э. [Горончаровский, 2013, с. 230-233].

Бронзовые двудырчатые псалии Г-образной формы - одни из распространенных в скифское время. В.Ю. Мурзин относит время их 
бытования к концу VI - V в. до н.э. [Мурзин, 1984, c. 80].

Наибольшая концентрация находок Г-образных двудырчатых псалиев приходится на памятники Лесостепной Скифии: О.Д. Могиловым учтено здесь более трех десятков экземпляров [Могилов, 2008 , с. 34 , рис. 66,10 $15 ; 67 ; 68]$, в том числе и «строгих», с парными выступами-шипами [Могилов, 2008, рис. $67,12,13$; рис. 68,5$]$. Встречены подобные псалии и в курганных погребениях степной Скифии: I Завадская могила [Мозолевский, 1980 , рис. $36,11,12$; рис. $37,1,2$; рис. $38,1,2]$, IV Испанова могила [Мозолевский, 1980, рис. 83,1 ; Мурзин, 1984 , с. 24 , рис. 12,1$]$.

Представительная коллекция Г-образных двудырчатых псалиев происходит из раскопок курганного некрополя боспорского города Нимфея: они входили в состав уздечных наборов из курганов 17 и 241876 г., гробницы 14 кургана 321876 г., кургана 11878 г. [Силантьева, 1959 , рис. $37,1,4$; рис. 40,1 ; рис. $47,2,3$; рис. 48,7$]$. Содержащие Г-образные псалии курганные погребения некрополя Нимфея датируются Л.Ф. Силантьевой в пределах V в. до н.э.: курган 241876 г. - серединой V в. до н.э., курган 171876 г. - серединой - третьей четвертью V в. до н.э., курган 11878 г. - серединой второй половиной $\mathrm{V}$ в. до н.э., гробница 14 кургана 321876 г. - первыми тремя четвертями V в. до н.э. [Силантьева, 1959, с. 71, 78, 83, 86].

Уздечный набор, содержащий бронзовые Г-образные псалии, входил в состав погребального инвентаря 11-го Ульского кургана в Закубанье [Габуев, Эрлих, 2001, с. 116, рис. 4,10].

Г-образные псалии встречены в IV Ceмибратнем кургане и в одном из Малых Семибратних курганов [Коровина, 1957, с. 183, рис. 1,1$]$, поблизости от которых найден публикуемый комплекс. Датировки, предложенные исследователями для IV Семибратнего кургана, укладываются во вторую половину $\mathrm{V}$ в. до н.э.: наиболее вероятной датой сооружения кургана, на основании содержащейся в комплексе инвентаря чернолаковой чаши 440 430 гг. до н.э., В.А. Горончаровский считает третью четверть V в. до н.э. [Горончаровский, 2013, с. 230-233].

Таким образом, комплекс бронзовых псалиев, найденный на пашне в районе Семибратних курганов, может быть датирован в пре- делах V в. до н.э. Псалии с серповидной лопастью повторяют аналогичную находку из $\mathrm{V}$ Семибратнего кургана, псалии Г-образной формы выполнены в традиции, широко распространенной в указанное время в погребальных памятниках Скифии, Европейского и Азиатского Боспора, Закубанья. В Семибратних курганах эта традиция до настоящего времени была представлена находками из IV Ceмибратнего и одного из Малых Семибратних курганов.

Находка комплекса металлических предметов конской узды в межкурганном пространстве нуждается в объяснении. Вполне возможно, что эти предметы происходят из невысокого, подвергшегося распашке кургана. Подобные неприметные насыпи вполне могли входить в курганную группу. Судя по отчетной документации, один такой едва различимый курган был исследован Анапской археологической экспедицией на некрополе Семибратнего городища в 1979 г. [Трейстер, 1979, с. 131-139; Алексеева, Шавырин, 1980, с. 92]. Годом ранее к западу от городища при земляных работах была потревожена сырцовая гробница, из которой происходит поступившая в Анапский археологический музей ручка бронзового ковша-киафа [Трейстер, 1979, c. 131]. Из разрушенного вспашкой погребения происходит, возможно, кинжал-акинак VI первой половины V в. до н.э., найденный на винограднике у хут. Чекон и хранящийся в Краснодарском государственном историко-археологическом музее им. Е.Д. Фелицына [Пьянков, Хачатурова, 2003, с. $60,62,63$, рис. 2,1$]$.

Но нельзя исключать и другого варианта объяснения находки уздечных принадлежностей в межкурганном пространстве. Современные исследования скифских Келермесских и Александропольского курганов показали, что в прикурганном и межкурганном пространстве совершались погребения, причем если в Келермессе это был некрополь местного меотского населения [Галанина, 1985, с. 156-165], то в Александрополе - связанные с поминальными обрядами человеческие жертвоприношения, сопровождавшимися обильными тризнами, от которых сохранились многочисленные фрагменты амфор и костей животных [Полин, 2011, с. 214-218; Полин, Дараган, 2010, c. 194-201]. Среди находок из внекурганных 
комплексов Александропольского кургана имеются железные удила и псалии [Полин, 2011, с. 215; Полин, Дараган, 2010, с. 197]. Следы околокурганных тризн и жертвоприношений обнаружены и вблизи других курганов скифской знати [Полин, 2011, с. 213, 214]. В 2030 м от скифского кургана Плоская могила в углублении были найдены более 250 бронзовых блях, некогда украшавших погребальную повозку и лошадей, а на пашне близ кургана Чмырева могила в XIX в. и в 1970-е гг. находили бронзовые навершия, также от погребальных повозок [Полин, 2011, с. 214].

Отметим, что использование погребальных повозок предполагает применение пароконной упряжки, а в нашем случае найдены как раз две пары псалиев. Раскопки скифских Александропольского и Краснокутского курганов показали, что повозки погребального кортежа могли оставляться у края курганной насыпи около крепиды [Мелюкова, 1981, с. 1012; Полин, Дараган, 2010, с. 195] и, как показывает исследование С.В. Полина, и в околокурганном пространстве.

Вполне возможно, что традиция помещения погребальной повозки или упряжи кативших ее лошадей в прикурганном пространстве появилась у кочевников Северного Причерноморья еще в предскифский период. В этом убеждают находки, сделанные при раскопках кургана 2 у с. Льговское в Крыму. В верхней части насыпи кургана было совершено погребение мужчины, сопровождавшееся железным кинжалом и набором бронзовых уздечных принадлежностей - удилами и псалиями новочеркасского типа. Два комплекта аналогичных удил и псалиев вместе с другими предметами конского снаряжения и оружием были найдены в прикурганном пространстве, еще один комплект таких же псалиев удил и вместе с бронзовой уздечной бляхой обнаружен в заполнении внутреннего рва [Рукавишникова, Бейлин, 2018, с. 262-265].

Внекурганные жертвенные комплексы известны и в раннесарматских могильниках. Так, при исследовании курганного могильника Филипповка I на значительном (от 40 до 200 м) удалении от насыпи самого большого в группе кургана 1 в разных местах были найдены металлические детали парадной мебели, бронзовый таз, фалар, два металлических доспеха, а в районе кургана 4 - два бронзовых ковша [Куринских и др., 2013, с. 182-185, $198,199]$. В раннесарматском курганном могильнике Прохоровка 1 в 150-200 м от кургана 1 обнаружен жертвенный комплекс, включавший пластинчатый железный доспех и парадный уздечный набор [Куринских и др., 2013, c. 199].

Анализируя внекурганные находки из раннесарматских памятников, Л.Т. Яблонский и его соавторы отмечают, что в силу существующей сегодня методики раскопок курганов подобные комплексы в большинстве случаев, обнаруживаются случайно [Куринских и др., 2013, с. 199]. И хотя Малые Семибратние курганы не подвергались современным раскопкам, публикуемый комплекс - очередное тому подтверждение.

Тем не менее, несмотря на случайные обстоятельства обнаружения и на невозможность привязки к какой-либо из курганных насыпей, эта находка расширяет наши представления о погребально-поминальной обрядности синдской знати, позволяя связывать ее с традициями, существовавшими в скифском и раннесарматском обществах. 

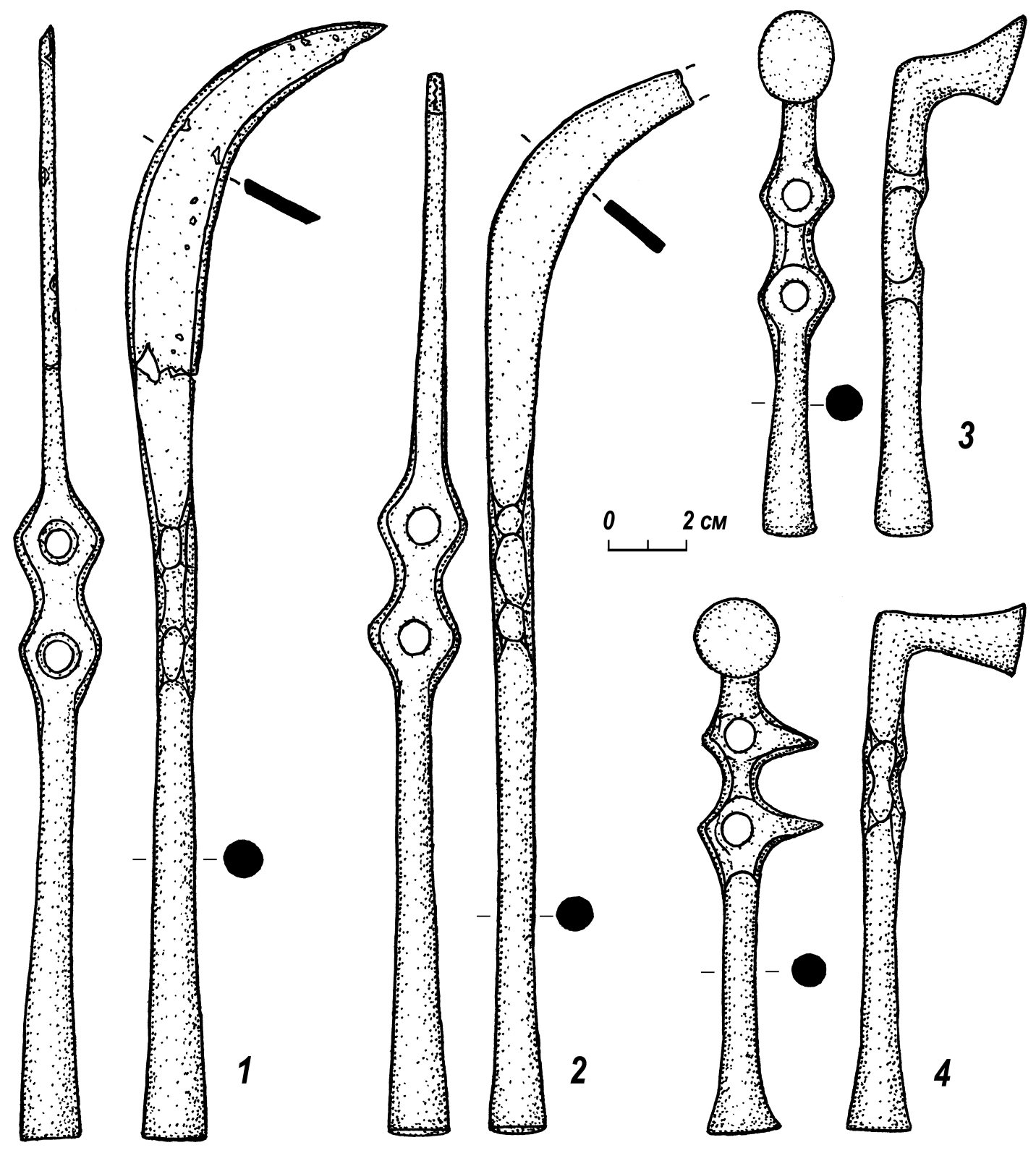

Рис. 1. Комплекс псалиев из района Малых Семибратних курганов. Бронза

Fig. 1. Complex of snaffles from the area of Malye Semibratnye barrows. Bronze 


\section{СПИСОК ЛИТЕРАТУРЫ}

Алексеева Е. М., Шавырин А. С., 1980. Исследования в Анапе и Анапском районе // Археологические открытия 1979 г. М. : Наука. С. 91-92.

Власова Е. В., 2001. Семибратние курганы // Боспорский феномен: колонизация региона, формирование полисов, образование государства : материалы Международной научной конференции. Ч. 2. СПб. : Изд-во Гос. Эрмитажа. С. 127-132.

Власова Е. В., 2010. Древности эллинские и местные // Античное наследие Кубани. Т. 3. М. : Наука. С. 198-262.

Габуев Т. А., Эрлих В. Р., 2001. Два погребения V в. до н.э. из Предкавказья (из материалов Государственного музея Востока) // Северный Кавказ : историко-археологические очерки и заметки : материалы и исследования по археологии России. № 3. М. : ИА РАН. С. 112-125.

Галанина Л. К., 1985. К проблеме взаимоотношений скифов с меотами (по данным новых раскопок Келермесского курганного могильника) // Советская археология. № 3. С. 156-165.

Горончаровский В. А., 2013. О хронологии Семибратних курганов // Третья Абхазская международная археологическая конференция: Проблемы древней и средневековой археологии Кавказа : материалы. Сухум : ИИМК РАН : Абхазский Институт гуманитарных исследований им. Д. И. Гулиа АН Абхазии : РУП «Дом печати». С. 230-233.

Коровина А. К., 1957. К вопросу об изучении Семибратних курганов // Советская археология. № 2. С. 174-187.

Куринских О. И., Мещеряков Д. В., Равич И. Г., Соловьева Л. Н., Трейстер М. Ю., Чугаев А. В., Яблонский Л. Т., 2013. Детали парадного трона ахеменидского типа из Филипповки // Вестник древней истории. № 2. С. 180-203.

Мелюкова А. И., 1981. Краснокутский курган. М. : Наука. 110 c.

Могилов О. Д., 2008. Спорядження коня скіфської доби у Лісостепу Східної Европи. Київ ; Кам’ янець Подільський : Інститут археології НАН. 439 с.

Мозолевский Б. Н., 1980. Скифские курганы в окрестностях г. Орджоникидзе на Днепропетровщине (раскопки 1972-1975 гг.) // Скифия и Кавказ. Киев : Наукова думка. С. 70-154.

Мурзин В. Ю., 1984. Скифская архаика Северного Причерноморья. Киев : Наукова думка. 134 с.

Полин С. В., 2011. К истории развития методики раскопок больших скифских курганов // Греческие и варварские памятники Северного Причерноморья: Опыт методики российских и украинских полевых исследований. М. ; Киев : ИА РАН. С. 206-222.

Полин С. В., Дараган М. Н., 2010. Работа на Александропольском кургане в 2008 г. // $\mathrm{YMBO} \Lambda \mathrm{A}$. Античный мир Северного Причерноморья. Новые находки и открытия. Вып. 1. М.; Киев : ИА РАН. С. 191-209.

Пьянков А. В., Хачатурова Е. А., 2003. Материалы предскифского и скифского времени из фондов Краснодарского музея-заповедника (Hекоторые неопубликованные находки последних десятилетий) // Материалы и исследования по археологии Кубани. Вып. 3. Краснодар : КубГУ. С. 59-66.

Рукавишникова И. В., Бейлин Д. В., 2018. Курган № 2 из группы из двух курганов (Республика Крым, Ленинский район) // Города, селища, могильники. Раскопки 2017 : материалы спасательных археологических исследований. Т. 25. М. : ИА РАН. С. 258-267.

Салов А. И., 1979. Материалы для археологической карты Анапского района // Краткие сообщения Института археологии. Вып. 159. С. $98-102$.

Силантьева Л. Ф., 1959. Некрополь Нимфея // Некрополи боспорских городов. Материалы и исследования по археологии СССР. № 69. М. ; Л. С. 5-107.

Трейстер М. Ю., 1979. Археологические работы в районе Семибратнего городища // НА АМ. А-1-25. Алексеева Е. М. Отчет о работе Анапской экспедиции в 1979 г. С. 131-139.

Тункина И. В., 2010. История изучения // Античное наследие Кубани. Т. 1. М. : Наука. С. 20-129.

\section{REFERENCES}

Alekseeva E.M., Shavirin A.S., 1980. Research in Anapa and Anapa district. Arckheologicheskie otkritiya 1979 goda. Moscow, Nauka Publ., pp. 91-92. (in Russian).

Vlasova E.V., 2001. Semibratnie barrows. Bosporskiy phenomen: colonozatsiya regiona, formirovanie polisov, obrazovanie gosudarstva. Materialy megdunarodnoy nauchnoy conferencii, p. 2. Saint-Petersburg, State Hermitage Museum, pp. 127-132. (in Russian).

Vlasova E.V., 2010. Antiquities Hellenic and local. Antichnoe nasledie Kubani, vol. 3. Moscow, Nauka Publ., pp. 198-262. (in Russian).

GabuevT.A., Erlikh V.R., 2001. Twoburials of the V century $\mathrm{BC}$ from Ciscaucasia (from the materials of the State Museum of the East). Severniy Kavkaz: istoririko-arckheologicheskie ocherki i zametki. Moscow, IA RAS Publ., pp. 112-125. (in Russian). 
Galanina L.K., 1985. On the problem of the relations between the Scythians and the Meotes (according to data obtained through new archaeological excavations of the Kelermesskaya mound burial). Sovetskaya arkheologiya, no. 3, pp. 156-165. (in Russian).

Goroncharovsky V.A., 2013. About chronology of Semibratnie barrows. Tretya Abhazskaya arkheologicheskaya conferenciya: Problemy drevney I srednevekovoy arkheologii Kavkaza. Materialy. Sukhum, Dom Pechaty Publ., pp. 230233. (in Russian).

Korovina A.K., 1957. To the question about learning Semibratnie barrows. Sovetskaya arkheologiya, no. 2, pp. 174-187. (in Russian).

Kurinskih O.I., Mescheryakov D.V., Ravich I.G., Solovyova L.N., Treister M.Yu., Chugaev A.V., Yablonsky L.T., 2013. Details of an AchaemenidStyle Ceremonial Throne from Filippovka, Journal of Ancient History, no 2, pp. 180-203. (in Russian).

Melyukova A.I., 1981. Krasnokutsky barrow. Moscow, Nauka Publ. 110 p. (in Russian).

Mogilov O.D., 2008. Equipment of the Scythian horse in the forest-Steppe of Eastern Europe. Kiev; Kamenets Podolsky, IA NAS Publ. 439 p. (in Russian).

Mozolevsky B.N., 1980. Scythian burial mounds near the town of Ordzhonikidze, in the Dnipropetrovsk region (excavations of 19721975). Skifiya I Kavkaz. Kiev, Naukova dumka Publ, pp. 70-154. (in Russian).

Murzin V.Yu., 1984. Scythian archaic of the Northern Black Sea region. Kiev, Naukova dumka Publ. 134 p. (in Russian).

Polin S.V., 2011. On the history of the development of methods of excavation of large Scythian burial mounds. Grecheskie I varvarskie pamyatniki Severnogo Prichernomorya: Opit metodiki rossiyskih I ukrainskih polevih issledovaniy. Moscow; Kiev, IA RAS Publ., pp. 206-222. (in Russian).

Polin S.V., Daragan M.N., 2010. Work on the

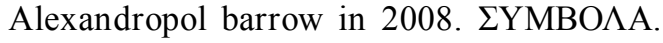
Antichniy mir Severnogo Prichernomorya. Novie nahodki i otritiya, iss. 1. Moscow; Kiev, IA RAS Publ., pp. 191-209. (in Russian).

Pyankov A.V., Khachaturova E.A., 2003. Materials of the pre-Scythian and Scythian time from the funds of the Krasnodar Museum-reserve (some unpublished finds of the last decades). Materialy $i$ issledovaniya po arckheologi Kubani, iss. 3. Krasnodar, KubSU, pp. 59-66. (in Russian).

Rukavishnikova I.V., Beylin D.V., 2018. Barrow № 2 from the group of two barrows (Republic of Crimea, Leninsky district). Goroda, selischa, mogilniki. Raskopki 2017. Materialy spasatelnich arkheologicheskih issledovaniy, vol. 25. Moscow, IA RAS Publ., pp. 258-267. (in Russian).

Salov A.I., 1979. Materials for the archaeological map of Anapa district. Kratkie soobscheniya Instituta arkheologii, iss. 159, pp. 98-102. (in Russian).

Silantyeva L.F., 1969. Necropolis of Nymphaeum. Nekropoli Bosporskih gorodov. Materialy $i$ issledovaniya po arkheologii SSSR, no. 69. Moscow; Leningrad, pp. 5-107. (in Russian).

Treister M.Yu., 1979. Archaeological work in the area of the Semibratnee hillfort. Nauchniy arkhiv Anaskogo arckheologicheskogo museya, A-1-25. Alekseeva E.M. Otchet o rabote Anapskoy arckheologicheskoy ekspeditsii, pp. 131-139.

Tunkina I.V., 2010. History of study. Antichnoe nasledie Kubani, vol. 1. Moscow, Nauka Publ., pp. 20129. (in Russian).

\section{Information about the Author}

Andrey M. Novichikhin, Candidate of Sciences (History), Senior Researcher, Department of Funds, Anapa Archaeological Museum, Naberezhnaya St., 4, 353440 Anapa, Russian Federation, yazamat03@mail.ru,https://orcid.org/0000-0001-9878-2431

\section{Информация об авторе}

Андрей Михайлович Новичихин, кандидат исторических наук, старший научный сотрудник отдела фондов, Анапский археологический музей, ул. Набережная, 4, 353440 г. Анапа, Российская Федерация, yazamat03@mail.ru, https://orcid.org/0000-0001-9878-2431 